\title{
Antimicrobial activity of honeys from two stingless honeybee species and Apis mellifera (Hymenoptera: Apidae) against pathogenic microorganisms
}

\author{
Carolinie Batista Nobre da CRUZ1, Fabio Alessandro PIERI²*, Gislene Almeida CARVALHO-ZILSE², \\ Patrícia Puccinelli ORLANDI ${ }^{2}$, Carlos Gustavo NUNES-SILVA ${ }^{1}$, Luciana LEOMIL ${ }^{1}$ \\ 1 Universidade Federal do Amazonas. Programa de Pós-Graduação em Biotecnologia. Av. Gal. Rodrigo Octávio Jordão, 3000, Bairro Coroado I, CEP 69.077-000, Phone: +55 \\ (92) 3647-4230, Fax: +55 (92) 3647-4230. Manaus, Amazonas, Brazil. carol_nobre24@yahoo.com.br, cgustav0@ufam.edu.br, lucianaleomil@yahoo.com. \\ ${ }^{2}$ Fundação Oswaldo Cruz. Instituto Leônidas e Maria Deane. Rua Terezina 476, Adrianópolis, CEP: 69057-070, Phone: +55 (92) 3621-2323, Fax: +55 (92) 3621-2399. Manaus, \\ Amazonas, Brazil. pierifabio@hotmail.com, patricia_orlandi@amazonia.fiocruz.br. \\ 3 Instituto Nacional de Pesquisas da Amazônia. Coordenação de Pesquisas em Ciências Agronômicas. Av. André Araújo, 2936, Petrópolis, CEP: $69083-000$, Phone: +55 (92) \\ 3643-3281, Fax: +55 (92) 9642-3440. Manaus, Amazonas, Brazil. gislene@inpa.gov.br. \\ * Corresponding Author: pierifabio@hotmail.com
}

\section{ABSTRACT}

Honeys are described possessing different properties including antimicrobial. Many studies have presented this activity of honeys produced by Apis mellifera bees, however studies including activities of stingless bees honeys are scarce. The aim of this study was to compare the antimicrobial activity of honeys collected in the Amazonas State from Melipona compressipes, Melipona seminigra and Apis mellifera against Staphylococcus aureus, Enterococcus faecalis, Escherichia coli, Chromobacterium violaceum, and Candida albicans. Minimum inhibitory concentrations were determined using the agar dilution method with Müller-Hinton agar (for bacteria) or Saboraud agar (for yeast). Staphylococcus aureus and E. faecalis were inhibited by all honeys at concentrations below $12 \%$, while $E$. coli and $C$. violaceum were inhibited by stingless bee honeys at concentrations between 10 and 20\%. A. mellifera honey inhibited E. coli at a concentration of $7 \%$ and Candida violaceum at $0.7 \%$. C. albicans were inhibited only with honey concentrations between 30 and 40\%. All examined honey had antimicrobial activity against the tested pathogens, thus serving as potential antimicrobial agents for several therapeutic approaches.

KEYWORDS: Melipona, antibacterial, antifungal, natural products, functional food

\section{Atividade antimicrobiana de méis de duas espécies de abelhas sem ferrão e Apis mellifera (Hymenoptera, Apidae) contra micro-organismos patogênicos}

\section{RESUMO}

Méis são descritos possuindo diferentes propriedades, incluindo a antimicrobiana. Muitos estudos têm apresentado essa atividade de méis produzidos por abelhas Apis mellifera, no entanto estudos incluindo atividades de méis de abelhas sem ferrão são escassos. O objetivo deste estudo foi comparar a atividade antimicrobiana de méis de Melipona compressipes, Melipona seminigra e A. mellifera, coletados no Estado do Amazonas, contra Staphylococcus aureus, Enterococcus faecalis, Escherichia coli, Chromobacterium violaceum, e Candida albicans. As concentraçóes inibitórias mínimas foram determinadas usando o método de diluição em ágar, com ágar Muller-Hinton (para bactérias) ou ágar Sabouraud (para a levedura). S. aureus e E. faecalis foram inibidos por todos os méis em concentraçóes inferiores a $12 \%$, enquanto $E$. coli e $C$. violaceum foram inibidos por méis de abelhas sem ferrão em altas concentraçóes entre 10 e 20\%. A. mellifera inibiu E. coli na concentração de $7 \%$ e C. violaceum em baixa concentração (0,7\%). C. albicans foi inibida apenas em concentraçóes entre 30 e $40 \%$ dos méis. Assim, todas as variedades de mel testadas apresentaram atividade antimicrobiana sobre os patógenos testados, servindo assim como agente antimicrobiano potencial para diversas abordagens terapêuticas.

PALAVRAS CHAVE: Melipona, antibacteriano, antifúngico, produtos naturais, alimentos funcionais 
For dietary purposes, honey is an excellent supplementary food with a high-energy component due to its sugar content (Evangelista-Rodrigues et al. 2005), mineral salts and other nutritional substances (Souza et al. 2004). Honey is composed primarily of the simple sugars glucose and fructose. It also contains sucrose and $17-20 \%$ of water, (Kamal and Klein 2011). In addition to being a natural sugar source, honey has been shown to have immunological, antibacterial, antifungal, antioxidant and anti-inflammatory properties (Bean 2012; Chen et al. 2012; Deravajan and Venugopal 2012). Honey is produced by numerous species of bees and their chemical composition may vary according to the habitat of each species. The Hymenoptera order includes approximately 2500 species of bees, primarily distributed in the southern continents (Almeida and Danforth 2009). Among the Hymenoptera, social bees are distributed in the Apidae family, which consists of 53 genera and approximately 300 species with a pantropical distribution (Michener 2007). In addition to the well-known honeybee (Apis mellifera), there are also stingless bees from the Apidae and Meliponini families that were the only species that produced honey in Brazil prior to the introduction of the European honeybee (Kerr et al. 2001). The interest in management and conservation of the stingless bees is justified because the ecological implications for the pollination of native crops, the high therapeutic value credited to their honey and pollen, and also the economic contributions of the honey industry (Kerr et al. 1996). Despite the extensive use of honey from stingless bees in home remedies, especially in traditional communities of the Amazon, a majority of previous studies have been conducted using honey from the Apis species (Carvalho-Zilse and Kerr 2006). As there are no studies evaluating the antimicrobial activity of honeys these species of stingless bee, the aim of this study was to compare the antimicrobial activity of honeys collected in the Amazonas State (Brazil) from Melipona compressipes, M. seminigra and $A$. mellifera against five different human pathogenic microorganisms: Staphylococcus aureus, Enterococcus faecalis, Escherichia coli, Chromobacterium violaceum, and Candida albicans.

For each stingless bee species included in the study, 300 $\mathrm{mL}$ of honey was obtained, in a single collection, using a disposable syringe to sample directly from the honey pots of bee colonies located at the National Amazon Institute of Research (INPA, Manaus, Brazil). Honey from Apis mellifera, which originated from a commercial apiary, was purchased at a local market in a single collection. Reference strains $S$. aureus (ATCC 25923), E. faecalis (ATCC 29212), E. coli (ATCC 25922), C. violaceum (ATCC 12472) and C. albicans (ATCC 90028) were maintained in Lignières slants at $4^{\circ} \mathrm{C}$ and for use, they were streaked in the same culture media and incubated at $37^{\circ} \mathrm{C}$. Lignières medium contained, per liter of distilled water, $8 \mathrm{~g}$ of nutrient broth (Oxoid, Basingstoke, United Kingdom), $5 \mathrm{~g}$ of gelatin (Fluka Analytical, Saint Gallen, Switzerland), and $7 \mathrm{~g}$ of agar (Himedia, Mumbai, India); $\mathrm{pH}$ was adjusted to 7.4 with $\mathrm{NaOH}$. Following Clinical and Laboratory Standards Institute guidelines (CLSI, 2006), minimum inhibitory concentrations (MICs) were determined using the agar dilution method in Petri dishes filled with Müller-Hinton agar (for bacteria) (Himedia) or Sabouraud dextrose agar (for yeast) (Oxoid). One colony of each ATCC sample was seeded in tubes containing $3 \mathrm{~mL}$ of Luria-Bertani (LB) (Acumedia, Michigan, United States) medium and incubated at $37^{\circ} \mathrm{C}$ until reaching $1.5 \times 10^{8} \mathrm{UFC} / \mathrm{mL}$. Culture medium was supplemented with decreasing concentrations of honey between $50 \%$ and $0,2 \%(\mathrm{v} / \mathrm{v})$. We used as control a culture medium supplemented with sucrose in the same concentrations. Bacterial suspensions $(10 \mu \mathrm{L})$ were then inoculated in spots onto media/honey plates and incubated at $37^{\circ} \mathrm{C}$ for $18 \mathrm{hr}$. Plates containing Müeller-Hinton agar and Saboraud agar without honey were used as negative controls. Each experiment was performed in triplicate.

A summary of assay results is presented in Table 1 . The antimicrobial assay showed the antimicrobial activity of honeys against different organisms. S. aureus and E. faecalis were inhibited by all honeys at concentrations less than $12 \%$ $\mathrm{v} / \mathrm{v}$, while $E$. coli and C. violaceum were inhibited by stingless bee honeys at high concentrations between 10 and $20 \% \mathrm{v} / \mathrm{v}$. A. mellifera honey inhibited $E$. coli at a concentration of $7 \%$ v/v and C. violaceum at $0.7 \% \mathrm{v} / \mathrm{v}$ (Table 1). C. albicans was observed to be the most resistant microorganism, requiring honey concentrations between 30 and $40 \% \mathrm{v} / \mathrm{v}$ to inhibit growth (Table 1). In sensitivity tests, honey from $A$. mellifera, $M$. seminigra and $M$. compressipes inhibited the growth of the microorganisms included in the study (Table 1). Honey from A. mellifera showed a higher inhibitory capacity against growth of $E$. coli and C. violaceum, which was evident by the lower MIC ( $7.0 \%$ and $0.7 \% \mathrm{v} / \mathrm{v}$, respectively). Conversely, honey from $M$. compressipes was had a higher inhibitory capacity against S. aureus and C. albicans (MIC 7.0\% and 30\% v/v, respectively) (Table 1). The honey from $M$. seminigra was the

Table 1 - Minimal inhibitory concentration (\% v/v) of honeys from Apis mellifera, Melipona compressipes and Melipona seminigra against five human pathogens.

\begin{tabular}{|c|c|c|c|c|c|}
\hline & S. aureus & E. faecalis & E. coli & C. violaceum & C. albicans \\
\hline A. mellifera & 7.0 & 10.0 & 7.0 & 0.7 & 40 \\
\hline M. seminigra & 8.0 & 5.5 & 16.0 & 10.0 & 35 \\
\hline M. compressipes & 7.0 & 7.5 & 20.0 & 20.0 & 30 \\
\hline
\end{tabular}


most efficient only against the E. faecalis strain (MIC 5.5\% $\mathrm{v} / \mathrm{v})$. Sucrose control mediums did not inhibit any strain used in this work in concentrations tested.

In this study, honey from M. compressipes, M. seminigra and A. mellifera had a wide range of antimicrobial activities against bacteria and yeast. All kind of honey examined displayed some antibacterial activity (Table 1 ). The lowest MIC observed was $0.7 \% \mathrm{v} / \mathrm{v}$ against $C$. violacium, while the highest was $40 \% \mathrm{v} / \mathrm{v}$ against $C$. albicans. The observed MIC value of $7 \% \mathrm{v} / \mathrm{v}$ against $E$. coli and $S$. aureus is displayed according Lusby et al. (2005), which reported a MIC of $5 \%$ against these same microorganisms using honey from $A$. mellifera. Chan-Rodrigues et al. (2012) reported inhibition of $S$. aureus, E. coli and E. faecalis with lower MICs using honey from Melipona beecheii compared to honey from A. mellifera. The results of the present study showed susceptibility of $S$. aureus to honeys from M. seminigra and M. compressipes with MICs between $7-8 \%$, which are similar MIC value to the $5 \%$ MIC previously observed for honey from $M$. beecheii. However, results were different of previous studies against $E$. coli and E. faecalis. Specifically, honeys tested in the current study were more effective against $E$. faecalis with MICs between 5.5-7.5\% compared to MICs between $10-15 \%$ in the study by Chan-Rodrigues et al. (2012). Although investigating different strains of E. coli, Chan-Rodrigues et al. (2012) observed MICs that were $5-15 \%$ lower than values reported for $E$. coli in the current study, which ranged from $16-20 \%$. Furthermore, Chan-Rodrigues et al. (2012) reported higher MICs for honey from A. mellifera. Specifically, MICs of 15, 20 and $25 \%$ were observed for $S$. aureus, E. coli and E. faecalis, respectively. Whereas, MICs of 7.0, 7.0 and 10\%, respectively, were observed in the current study. With MICs between $30-40 \%$, C. albicans was determined to be the most resistant microorganism included in the current study. These results are not consistent with Demera and Angert (2004), who reported greater susceptibility of $C$. albicans to honeys from $A$. mellifera and Tetragonisca angustula. A possible explanation for these differences may be the variable composition of tested honey. In addition to the honeybee species, floral origin may also influence honey composition. General variations observed in overall antibacterial activity have been attributed to variation in the concentration of hydrogen peroxide in the honey and, in some cases, to the concentration of non-peroxide factors (Molan 1992). In some works the strains were different of those used in the current study. In these cases, other possible explanation may be that different bacterial strains possess different antimicrobial susceptibilities (Pieri et al. 2012). However, S. aureus strain (ATCC 25923) used in the current study was the same used by Chan-Rodrigues et al. (2012) indicating that differences in results for honey from A. mellifera likely occurred due different honey composition. Same conclusion could be related to differences between the results against C. albicans (ATCC 90028) by Demera and Angert (2004) and the findings of present study once the strains used were the same. Importantly $C$. violaceum has been reported as an infectious agent to humans and animals worldwide, including Amazon region, especially being transmitted by water (Perez et al. 2007). No previous studies have investigated the inhibition of $C$. violaceum by honeys from Melipona spp. and Apis spp. bees, with special reference to honey of $A$. mellifera who obtained very low MIC value and could be a promising antimicrobial agent to treat infections of these bacteria. Alves et al. (2008) demonstrated a practical therapeutic use for honey made by different bee species of the genus Melipona (M. subnitida) in cutaneous wound healing in rats. The mean healing time of infected wounds was lower in honey-treated groups compared to control groups and they reported $100 \%$ eradication of Gramnegative bacteria on wound, as well as a significant reduction of Gram-positive bacteria. Alves et al. (2008) suggest that this activity was mainly due to hydrogen peroxide produced by glucose oxidase and may also be related to other characteristics such as low $\mathrm{pH}$ presented by honey tested, osmotic pressure, or other unknown factors phytochemicals. The antimicrobial activity demonstrated in vivo by Alves et al. (2008) supports by the results of the current study, which showed significant antimicrobial activity of honeys produced by two species of Melipona spp. However in the present study the factor osmotic pressure could be excluded due to non-inhibition of strains by the sucrose control. Further research is needed to determine the specific compounds responsible for this antimicrobial activity. In conclusion, all tested honey varieties possessed antimicrobial activity against several human pathogenic microorganisms, thus serving as potential antimicrobial agents for use in several therapeutic approaches.

\section{ACKNOWLEDGEMENTS}

The authors would like to thank Conselho Nacional de Desenvolvimento Científico e Tecnológico (CNPq), Coordenação de Aperfeiçoamento de Pessoal de Nível Superior (CAPES) and Fundação de Amparo à Pesquisa do Estado do Amazonas (FAPEAM) for financial support.

\section{REFERENCES}

Almeida, E.A.B.; Danforth, B.N. 2009. Phylogeny of colletid bees (Hymenoptera: Colletidae) inferred from four nuclear genes. Molecular Phylogenetics and Evolution, 50: 290-309.

Alves, D.F.S.; Cabral Junior, F.C.; Cabral, P.P.A.C.; Oliveira Junior, R.M.; Rego, A.C.M.; Medeiros, A.C. 2008. Effects of topical application of the honey of Melipona subnitida in infected wounds of rats. Revista do Colégio Brasileiro de Cirurgia, 35:188193. 
Bean, A. 2012. Investigating the Anti-inflammatory Activity of Honey. Tese de Doutorado, University of Waikato, Hamilton, New Zealand. 318p.

Carvalho-Zilse, G.A.; Kerr, W.E. 2006. Utilização de marcadores microsatelites para estudos populacionais em Melipona scutellaris (Apidae, Meliponini). Magistra, 18: 213-220.

Chan-Rodrigues, D.; Ramón-Sierra, J.; Lope-Ayora, J.; Sauri-Duch, E.; Cuevas-Glory, L.; Ortiz-Vázquez, E. 2012. Antibacterial Properties of Honey Produced by Melipona beecheii and Apis mellifera against Foodborn Microorganisms. Food Science Biotechnology, 21:905-909.

Chen, C.; Campbell, L.T.; Blair, S.E.; Carter, D.A. 2012. The effect of standard heat and filtration processing procedures on antimicrobial activity and hydrogen peroxide levels in honey. Frontiers in Microbiology, 3: 1-8.

CLSI. 2006. Methods for Dilution Antimicrobial Susceptibility Tests for Bacteria That Grow Aerobically; Approved Standard —Seventh Edition. CLSI, document M7-A7. Clinical and Laboratory Standards Institute, Wayne, 2006, 51p.

Demeraj.H.; Angert, E.R. 2004. Comparison of the antimicrobial activity of honey produced by Tetragonisca angustula (Meliponinae) and Apis mellifera from different phytogeographic regions of Costa Rica. Apidologie, 35:411-417.

Devarajan, S.; Venugopal, S. 2012. Antioxidant and $\alpha$-amylase inhibition activities of phenolic compounds in the extracts of Indian honey. Chinese Journal of Natural Medicines, 10:255-259.

Evangelista-Rodrigues, A.; Silva, E.M.S.; Beserra, E.M.F.; Rodrigues, M.L. 2005. Análise físico-química dos méis das abelhas Apis mellifera e Melipona scutellaris produzidos em duas regiôes no estado da Paraíba. Ciência Rural, 35:1166-1171.
Kamal, M.A.; Klein, P. 2011. Determination of sugars in honey by liquid chromatography. Saudi Journal of Biological Sciences, 18:17-21.

Kerr, W.E.; Carvalho, G.A.; Nascimento, V.A. 1996. Abelha Uruçu: Biologia, Manejo e Conservação. Acangaú, Belo Horizonte, 144p.

Kerr, W.E.; Carvalho, G.A.; Silva, A.C.; Assis, M.G.P. 2001. Aspectos pouco mencionados da biodiversidade amazônica. Parcerias estratégicas, 12:20-41.

Lusby, P.E.; Coombes, A.L.; Wilkinson, J.M. 2005. Bactericidal activity of different honeys against pathogenic bacteria. Archives of Medical Research, 36:464-467.

Michener C.D. 2007. The bees of the world. 2nd edn. Johns Hopkins University Press, Baltimore, 992p.

Molan, P.C. 1992. The antibacterial activity of honey: 2. Variation in the potency of the antibacterial activity. Bee World, 73:59-76.

Perez, J.A.D; Garcia, J.; Villamizar, L.A.R. 2007. Sepsis by Chromobacterium violaceum: First Case Report from Colombia. The Brazilian Journal of Infectious Diseases, 11:441-442.

Pieri, F.A.; Silva, V.O.; Souza, C.F.; Costa, J.C.M.; Santos, L.F.; Moreira, M.A.S. 2012. Antimicrobial profile screening of two oils of Copaifera genus. Arquivo Brasileiro de Medicina Veterinária e Zootecnia, 64:241-244.

Souza, R.C.S.; Yuyama, L.K.O.; Aguiar, J.P.L.; Oliveira, F.P.M. 2004. Valor nutricional do mel e pólen de abelhas sem ferrão da região amazônica. Acta Amazônica, 34:333-336.

Recebido em 15/03/2013

Aceito em 19/06/2013 